\title{
Biological study of the coccinellid predator, Stethorus punctillum under different constant temperatures
}

\author{
Bakr $^{1}$, R. F. A.; Genidy ${ }^{1}$ Noha A. M.; Gesraha' ${ }^{2}$ M. A.; Farag $^{2}$, N.A. and \\ Elbehery $^{2}$ Hoda H.A. \\ 1- Department of Entomology, Faculty of Science, Ain Shams University, Cairo, Egypt \\ 2- Department of Pests and Plant Protection, National Research Centre, Cairo, Egypt
}

\section{ABSTRACT}

The ladybeetle, Stethorus punctillum Wiese (Coccinellidae: Coleoptera), is one of the common predators for the two-spotted spider mite, Tetranychus urticae (Koch.). When this predator was reared under different constant temperatures $\left(15,25\right.$ and $\left.35^{\circ} \mathrm{C}\right)$, the duration of all stages decreased with increasing temperature. The optimum rearing temperature for this predator under laboratory conditions was found to be $25^{\circ} \mathrm{C}$. When the predator feed on alternative food source we found that no oviposition was recorded on any alternative foods, therefore, no eggs were deposited. There were difference in adult $S$. punctillum longevity associated with different alternative food they feed, the longest period recorded was 12.70 days when the predator feed on a mixture of honey droplets, pollen grains and royal jelly. The shortest periods recorded was 3.75 days when the predator was starved or 3.90 days when feed on aphid.

Keywords: Ladybeetle, Stethorus punctillum, Tetranychus urticae, biology.

\section{INTRODUCTION}

Several natural enemies of Tetranychus urticae were recorded all-over the world (Granham, 1985). Most species of Order Coleoptera, Family Coccinellidae are predators of spider mites (Felland and Hull, 1996; Hoy and Smith, 1982 and McMurty et al., 1970). The ladybeetles of genus Stethorus (Stethorus punctillum, S. gilvifrons, S. punctum picipes) were the most effective natural enemies of the phytophagous mite species Tetranychus piercei McGregor, Panonychus citri McGregor, Panonychus ulmi (koch) and Tetranychus urticae Koch (Lui and Lui, 1986; Lorenzato, 1987; Wen, 1988; Pasualini and Antropoli, 1994; Cakmak and Aksit, 2003; Gencer et al., 2005; James et al., 2001 and Perez et al., 2004).

Stethorus punctillum Weise is one of the most active coccinellid predators against the two-spotted spider mite. Their larval and adult stages feeding on the different stages of the two-spotted spider mites.

The aim of the present work is to figure out the effects of different tested temperatures on some biological parameters of the predator, S. punctillum in order to mass rearing and release under greenhouse and open-field conditions.

\section{MATERIALS AND METHODS}

\section{A- Experimental Materials}

\section{Culture of the prey, Tetranychus urticae}

Ten pots $(10 \mathrm{~cm}$ diameter) were sown with four cowpea seeds each at depth of $1 \mathrm{~cm}$. Pots were kept in the laboratory for 2 weeks before being infested artificially with $T$. urticae, which were collected from naturally infested castor oil plant leaves. 
Infested pots were transferred to wooden cage with nylon cloth on the top. After one week, the culture of mite was established and maintained as stock culture in the laboratory during the experiments.

\section{Culture of the predator, Stethorus punctillum}

The stock culture of ladybeetle was started with adult that were collected from different plant leaves, especially the castor oil plant leaves, which were infested with the red spider mite, T. urticae. The predator S. punctillum was reared on potted bean plants infested with $T$. urticae, which was maintained in the rearing cages for 2-3 months (permanent culture) before testing the predator efficiency.

Experimental cell

Plastic cells $(4 \times 3 \times 3 \mathrm{~cm}$ dimensions) with carton cover were used to carry out all experiments. A moistened cotton piece was placed inside each cell and disc of bean leaf was placed on the cotton during the experiment to maintain freshness of the leaf.

\section{B- Methods and Techniques}

\section{I- Duration of different stages of $S$. punctillum}

The duration was studied through out fifty newly deposited eggs and was followed-up till adult emergence.

\section{1- Incubation period}

Five pairs (females \& males) of $S$. punctillum were randomly selected from the stock culture; each pair was placed on a leaf disc $(2.5 \mathrm{~cm})$ infested with enough number of different mite stages, then kept in rearing cups. The cups were covered and incubated at each tested temperature $\left(15,25\right.$ and $\left.35^{\circ} \mathrm{C}\right)$. Deposited eggs were collected periodically ( 2 hours interval). Each newly deposited egg was carefully transferred separately in an experimental cell and incubated at the same tested temperature till hatch, the incubation period was recorded.

\section{2- Larval stage}

The newly hatched larvae were supplied daily with enough number of different stages of mite, incubated at the same temperature till moulting occurs. The duration of each larval instar was recorded.

\section{3- Pupal stage}

The pupated larvae resulted from previous step were incubated at the same tested temperature till adult emergence. The pupation period was recorded too.

\section{4- Adult stage}

Newly emerged adults resulted from previous step were kept on an infested leaf discs $(10 \mathrm{~cm})$ in rearing cups $(120 \mathrm{ml})$ and incubated at the same tested temperature over night to confirm mating occurrence.

Each adult was placed separately in an experimental cell and checked daily till death for males and egg laying for females. Preoviposition, oviposition and postoviposition periods were recorded. The number of eggs laid per female was recorded daily. The whole experiment was replicated five times.

\section{Alternative food sources}

In case of the lack of natural food supply (T. urticae), we try to fined out some alternative food sources.

Four groups of predators adult were used to study some biological aspects as a result of feeding on different food under the laboratory conditions. Each group contained fifteen newly emerged predators adult; each predator was placed in an experimental cell, supplied with a moistened piece of cotton to give a suitable humidity and one of the following alternative food kinds:
1- No food (starvation).
2- Honey droplets.
3- Whitefly (egg only).

4- Duranta aphids (Aphis durantii). 5- Pollen grains + honey droplets + royal jelly. 
The experimental cells were incubated under the tested temperatures. Lifespan and activity, were recorded till the death of the predator adults.

The whole experiment was replicated five times at each food source.

Statistical analysis: Data were subjected to analysis of variance (ANOVA) using "SPSS" computer statistical program. Mean values were compared using Duncan's Multiple Range teas.

\section{RESULTS}

\section{I- Duration of different stages of Stethorus punctillum}

Data in Table (1) clarify that the incubation period for eggs, the duration of the four larval instars and pupal stage as well were significantly affected $(P>0.01)$ with tested temperatures, whereas it was decreased with increasing the temperatures (15, 25 and $35^{\circ} \mathrm{C}$ ); being statistically different between each other (Table 1).

The mean duration of the total immature stages of $S$. punctillum was $34.1,13.3$ and 10.6 days, respectively, at 15,25 and $30^{\circ} \mathrm{C}$. Being statistically differ of each other $(P>0.01)$ (Table 1).

It can be concluded that the tested temperatures were affected negatively the duration of egg, larval and pupal stages (Table 1).

Table (1): Duration (in hours) of Stethorus punctillum immature stages at different temperatures

\begin{tabular}{|c|c|c|c|c|}
\hline \multirow{2}{*}{$\begin{array}{l}\text { Immature } \\
\text { Stages }\end{array}$} & \multicolumn{3}{|c|}{ Mean \pm SE } & \multirow[t]{2}{*}{ F- value } \\
\hline & $15^{\circ} \mathrm{C}$ & $25^{\circ} \mathrm{C}$ & $35^{\circ} \mathrm{C}$ & \\
\hline Egg stage & $\begin{array}{c}203.0 \pm 3.93 \mathrm{a} \\
(8.5)\end{array}$ & $\begin{array}{c}94.08 \pm 1.08 \mathrm{~b} \\
(3.9)\end{array}$ & $\begin{array}{c}69.87 \pm 1.16 \mathrm{c} \\
(2.9)\end{array}$ & $566.166^{* *}$ \\
\hline $1^{\text {st }}$ larval instar & $\begin{array}{c}96.31 \pm 1.72 \mathrm{a} \\
(4.0)\end{array}$ & $\begin{array}{c}39.97 \pm 0.83 \mathrm{~b} \\
(1.7)\end{array}$ & $\begin{array}{c}30.50 \pm 1.10 \mathrm{c} \\
(1.3)\end{array}$ & $660.814 * *$ \\
\hline $2^{\text {nd }}$ larval instar & $\begin{array}{c}75.52 \pm 1.50 \mathrm{a} \\
(3.2)\end{array}$ & $\begin{array}{c}28.70 \pm 1.09 \mathrm{~b} \\
(1.2)\end{array}$ & $\begin{array}{c}21.80 \pm 0.68 \mathrm{c} \\
(0.9)\end{array}$ & $527.101 * *$ \\
\hline $3^{\text {rd }}$ larval instar & $\begin{array}{c}83.48 \pm 1.21 \mathrm{a} \\
(3.5)\end{array}$ & $\begin{array}{c}28.10 \pm 0.50 \mathrm{~b} \\
(1.2)\end{array}$ & $\begin{array}{c}24.39 \pm 0.86 \mathrm{c} \\
(1.0)\end{array}$ & $1122.432 * *$ \\
\hline $4^{\text {th }}$ larval instar & $\begin{array}{c}169.96 \pm 1.42 \mathrm{a} \\
(7.1)\end{array}$ & $\begin{array}{c}56.38 \pm 1.79 \mathrm{~b} \\
(2.3)\end{array}$ & $\begin{array}{c}45.60 \pm 0.88 \mathrm{c} \\
(1.9)\end{array}$ & $2256.287 * *$ \\
\hline Larval stage & $\begin{array}{c}424.93 \pm 4.08 \mathrm{a} \\
(17.7)\end{array}$ & $\begin{array}{c}144.20 \pm 6.92 \mathrm{~b} \\
(6.0)\end{array}$ & $\begin{array}{c}122.00 \pm 1.80 \mathrm{c} \\
(5.1)\end{array}$ & $1207.532 * *$ \\
\hline Pupal stage & $\begin{array}{c}189.93 \pm 3.87 \mathrm{a} \\
(7.9)\end{array}$ & $\begin{array}{c}72.73 \pm 1.10 \mathrm{~b} \\
(3.0)\end{array}$ & $\begin{array}{c}62.42 \pm 0.74 \mathrm{c} \\
(2.6)\end{array}$ & $656.199 * *$ \\
\hline Total immature stages & $\begin{array}{c}819.21 \pm 5.99 \mathrm{a} \\
(34.1)\end{array}$ & $\begin{array}{c}319.95 \pm 3.04 \mathrm{~b} \\
(13.3)\end{array}$ & $\begin{array}{c}254.36 \pm 2.10 \mathrm{c} \\
(10.6)\end{array}$ & $4134.925 * *$ \\
\hline
\end{tabular}

Means in a raw followed with the same letter(s) are not significantly different at $5 \%$ level of probability.

$* *=$ Highly significant $\quad$ Numbers between brackets $=$ duration in days

As for the adult stage, data in Table (2) showed that, the mean longevity of male and female was negatively affected with increasing the temperatures. Being statistically different within each case $(P>0.01)$.

The same figure was observed for the oviposition periods; where as these periods were negatively affected with increasing temperature too.

The total number of eggs lied per female during its life span was $195.22 \pm 26.35,174.29 \pm 21.58$ and $118.64 \pm 11.70$ eggs, respectively at the same tested temperatures. Statistical analysis indicated that there was a significant difference between those reared at 15 and $35^{\circ} \mathrm{C}$; while those reared at $25^{\circ} \mathrm{C}$ had insignificant differences with other both tested temperatures $(P>0.05$ and $P<0.01)$ ( Table 2$)$. 
The total number of eggs laid per female per day was $2.68 \pm 0.14,3.59 \pm 0.20$ and $4.51 \pm 0.27$ eggs, respectively, at 15,25 and $35^{\circ} \mathrm{C}$; being statistically different between each other $(P>0.01)$ (Table 2$)$.

Table (2): Longevity (in days) of Stethorus punctillum adults and the number of eggs laid by female predator under the tested constant temperatures

\begin{tabular}{|l|c|c|c|c|}
\hline \multirow{2}{*}{\begin{tabular}{c}
\multirow{2}{*}{$\begin{array}{c}\text { Periods } \\
\text { (in days) }\end{array}$} \\
\cline { 2 - 5 }
\end{tabular}} & $15^{\circ} \mathrm{C}$ & $25^{\circ} \mathrm{C}$ & $35^{\circ} \mathrm{C}$ & \multirow{2}{*}{ F-value } \\
\hline Male longevity & $81.71 \pm 2.53 \mathrm{c}$ & $62.93 \pm 1.62 \mathrm{~b}$ & $38.38 \pm 2.96 \mathrm{a}$ & $78.181^{* *}$ \\
\hline Female longevity & $97.78 \pm 1.23 \mathrm{c}$ & $60.10 \pm 1.10 \mathrm{~b}$ & $32.81 \pm 2.08 \mathrm{a}$ & $310.351^{* *}$ \\
\hline Pre-oviposition & $9.22 \pm 0.27 \mathrm{c}$ & $4.15 \pm 0.19 \mathrm{~b}$ & $3.25 \pm 0.30 \mathrm{a}$ & $105.598^{* *}$ \\
\hline Oviposition & $78.34 \pm 1.27 \mathrm{c}$ & $51.40 \pm 1.46 \mathrm{~b}$ & $25.38 \pm 2.11 \mathrm{a}$ & $191.566^{* *}$ \\
\hline Post-oviposition & $10.22 \pm 0.62 \mathrm{~b}$ & $4.50 \pm 0.65 \mathrm{a}$ & $4.06 \pm 1.00 \mathrm{a}$ & $12.488^{* *}$ \\
\hline $\begin{array}{l}\text { Number of eggs: } \\
\text { Total eggs/female }\end{array}$ & $195.22 \pm 26.35 \mathrm{~b}$ & $174.29 \pm 21.58 \mathrm{ab}$ & $118.64 \pm 11.70 \mathrm{a}$ & $4.031^{*}$ \\
\hline Eggs/female/day & $2.68 \pm 0.14 \mathrm{c}$ & $3.59 \pm 0.20 \mathrm{~b}$ & $4.51 \pm 0.27 \mathrm{a}$ & $18.349^{* *}$ \\
\hline
\end{tabular}

Means in a raw followed with the same letter (s) are not significantly different at 5\% level of probability.

$* *=$ Highly significant $\quad *=$ Significant

\section{Alternative food sources}

The obtained results (Table 3 ) show that, no oviposition was recorded on any alternative food resources, therefore, no eggs were deposited. There were difference in adult $S$. punctillum longevity associated with different alternative food they feed, the longest period was recorded $(12.70 \pm 0.76$ days $)$ when the predator feed on a mixture of honey droplets + pollen grains + royal jelly; being statistically different with other alternative food $(P<0.01)$. The shortest period recorded when the predator was starved $(3.75 \pm 0.57$ days $)$ or feed on aphid ( $3.90 \pm 0.28$ days), respectively. When the predator feed on honey droplets or feed on whitefly eggs the recorded longevity was $5.20 \pm 0.33$ and $4.55 \pm 0.34$ days, respectively, being insignificantly different among each other $(P>0.05)$ (Table 3$)$.

From the forementioned results, it could be concluded that $S$. punctillum is specific predator and could not be reproduce when feed on any alternative food resources other than the two-spotted spider mite.

Table (3): Longevity (in days) of the predator Stethorus punctillum adult female, feed on different alternative food at room temperature

\begin{tabular}{|c|c|c|c|}
\hline Alternative foods & $\begin{array}{c}\text { Longevity } \\
\text { (in days) }\end{array}$ & $\begin{array}{c}\text { Mean number of } \\
\text { deposited eggs }\end{array}$ & $\begin{array}{c}(\%) \\
\text { Hatchability }\end{array}$ \\
\hline Starvation (control) & $3.75 \pm 0.57 \mathrm{a}$ & 0 & 0 \\
\hline Honey droplets & $5.20 \pm 0.33 \mathrm{a}$ & 0 & 0 \\
\hline White fly (eggs) & $4.55 \pm 0.34 \mathrm{a}$ & 0 & 0 \\
\hline Aphid (all instars) & $3.90 \pm 0.28 \mathrm{a}$ & 0 & 0 \\
\hline Honey+pollen+royal jelly & $12.70 \pm 0.76 \mathrm{~b}$ & 0 & 0 \\
\hline F-value & $59.235^{* *}$ & 0 & 0 \\
\hline
\end{tabular}

Means in a column followed with the same letter (s) are not significantly different at 5\% probability.

$* *=$ Highly significant 


\section{DISCUSSION}

In our study, in general, it was found that the duration of all stages of Stethorus punctillum decreased with increasing temperature; while on the contrary, the temperature positively affected the female fecundity and feeding capacity, which increased with increased temperature. Thus, $25^{\circ} \mathrm{C}$ was the optimum temperature for the predator development. The obtained results were agree with the results obtained by Iskander et al. (1994) and Shoeib (2001) for S. punctillum. Also, these results were matched with Ahmed and Ahmed (1989) for S. gilvifrons, on Tetranychus turkestani; Inam-Ullah (2000) for S. vegans and Naher and Haque (2005) for S. punctillum. But, it was shorter than those reported by Shen et al. (1999) for S. punctillum; Mridul and Badal (2002) for S. gilvifrons and Kasap and Aktug (2003) for S. punctillum.

\section{Alternative food sources}

Most coccinellids are predaceous on insect in the suborder Homoptera, but species in the genus Stethorus feed almost exclusively on spider mite. When primary prey is scare Stethorus are reported to eat other food source such as aphids, white flies, honeydew, pollen grains, nectar and sweet sap or may even elicit a cannibalistic behaviour. While some species of Stethorus feed on range of tetranychid species, other is more specialists, such as S. punctillum. S. gilvifrons do not readily feed or oviposit if they reared on some mite species.

Our given results indicated that there was no oviposition recorded for $S$. punctillum when fed on any tested alternative foods. That could be referred to that this predator is specific predator on Tetranychus urticae. This obtained result was contradicting with Inam-Ullah (2000) for S. vegans, where female predator laid their eggs when reared on water+pollen grains. Also, these results were in accordance with Hoy and Smith (1982) for S. nigripes; Helle and Sabelis (1985) for S. punctillum and S. fuerschi; Gu et al. (1996) and Shoeib (2001) for S. punctillum.

It was noticed that, the adult female longevity was longer when provision with alternative foods such as honey, aphids, whitefly-eggs and mixture of Honey+pollen+royal jelly, compared with the starved females (control). Where the latter mixture make the adult longevity longer than the other alternatives; since no significant difference was recorded between the rest of the tested alternative foods.

\section{REFERENCES}

Ahmed, Z.I. and Ahmed, N.R.F. (1989). Biological studies of predator Stethorus gilvifrons Mulsant (Coleoptera, Coccinellidae) on strawberry mite Tetranychus turkestani Ugarov and Nikolski (Acariformes, Tetranychidae). J. Biol. Sci. Res., 20 (1): 33-22.

Cakmak, I. and Aksit, T. (2003). Investigations on phytophagous mites, their natural enemies and the population fluctuations of important species on fig trees in Aydn (Turkey). Turkiye entomoloji dergisi. 27(1): 27-38.

Felland, C.M. and Hull, L.A. (1996). Overwintering of Stethorus punctum punctum (Coleoptera: Coccinellidae) in apple orchard ground cover. Enviromental Entomology, 25(5): 972-976.

Gencer, N.S; Coskuncu, K.S. and Kumral, N.A. (2005). Determination of harmful and beneficial fauna in fig orchards in Bursa Province. Ondokuz Mays Universitesi, Ziraat Fakultesi Dergisi, 20(2): 24-30. 
Granham, J. E. (1985). Hop. In: Helle, W. and Sabelis, M.W. [Eds.] Spider Mites. Their Biology, Natural Enemies and Control. Vol. 1B. Elsevier, Amsterdam, the Netherlands. 367-370.

Gu, Y.; Zhang, Y.C. and Zhang, Z.F. (1996). Study on the predation of Stethorus punctillum Wies to Tetranychus urticae (Koch). Natural enemies of insects. 18 (4): 163-166.

Helle, W. and Sabelis, M.W. (1985). Spider mites: their biology, natural enemies and control 1(B):211-245 Elsevier Sci. Publis., Amsterdam, The Netherlands.

Hoy, M.A. and Smith, K.B. (1982). Evaluation of S. nigripes (Coleoptera: Coccinellidae) for biological control of spider mites in California almond orchards. Entomophaga, 27(3): 301-310

Inam-Ullah, K. (2000). Aspects of the biology of the ladybird beetle, Stethorus vagans (Blackburn) (Coleoptera: Coccinellidae). Ph. D. Thesis, Univ. Western Sydney, Hawkesbury. 183pp.

Iskander, N.G.; Sedrak, R.A. and Ibrahim, S.M. (1994). Studies on development, fecundity and predation efficiency of Stethorus puncillum Weis (Coccinellidae: Coleoptera) on the red spider mite, Tetranychus arabicus Attiah (Acari: Tetranychidae). Egypt. J. Appl. Sci., 9 (8): 330-338.

James, D.G.; Price, T.; Wright, L.C.; Coyle, J. and Perez, J. (2001). Mite abundance and phenology on commercial and escaped hops in Washington State, USA. Internat. J. Acarol., 27(2): 151-156.

Kasap, I. and Aktug, Y. (2003). Studies on some biological parameters of Stethorus punctillum Weise (Coleoptera: Coccinellidae) feeding on spider mite species (Acarina: Tetranychidae) at laboratory conditions. Turkiye entomoloji dergisi, 27 (2): 113-122.

Lorenzato, D. (1987). Biological control of phytophagous mites in apple orchards in Farroupilha, RS. Agronomia Sulriograndense. publ. 1988, 23 (2): 167-183.

Lui, Z. and Lui, N.Z. (1986). A preliminary report on Tetranychus pierce McGregor. Insect Knowledge, 23 (1): 18-19.

McMurtry, J.A,; Huffaker, C.B. and van de Vrie, M. (1970). Ecology of Tetranychus mites and their natural enemies: Their biological characters and the impact of spray particles. Hilgardia, 40(1): 331-339.

Mridul, S. and Badal, B. (2002). Biology and feeding potential of Stethorus gilvifrons Mulsant (Coccinellidae: Coleoptera) on tea red spider mite, Oligonychus coffeae Neitner. Shashpa; 9 (1): 23-26.

Naher, W.I. and Haque, M.M. (2005). Predation of three predators on two-spotted spider mite, Tetranychus urticae Koch (Acari: Tetranychidae). Life Earth Science, 1 (1): 1-4.

Pasualini, E. and Antropoli, A. (1994). Stethorus punctillum. Informatore Fitopatologico, 44 (5): 33-36.

Perez, R.P.; Almaguel, L.; Caceres, I.; Feito, E. and Torre, E. (2004). The predators of Tetranychus tumidus Banks in Cuba. Fitosanidad, 8 (1): 47-50.

Shen, M.; Guo, Z. and Xiong, J. (1999). Influence of temperature on the experimental population of Stethorus punctillum. Acta Ecologica Sinica, 18 (2): 1-2.

Shoeib, Amira A. (2001). Effect of food types and temperatures on biological aspects and fecundity of the predator insect Stethorus puncillum Weise (Coccinellidae). Egypt. J. Appl. Sci., 16 (9): 242-250.

Wen, H.C. (1988). Seasonal occurrence and chemical control of the citrus red mite, Panonychus citri (McGregor) on Caramble. J. Agric. Res. China, 37 (1): 100104. 


\section{ARABIC SUMMERY}

دراسات بيولوجية للمفترس (ستيثورس بنكتيلم ) عند درجات الحرارة المختلفة

رضا فضيل على بكر 1، نهى عونى محمد جنيدى 1، محمد أحمد جسرها2 ، ناجى عبد اللطيف فرج² 2

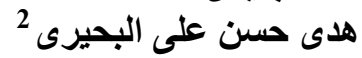

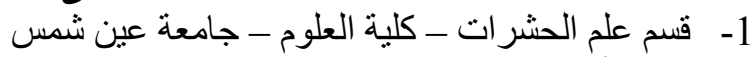

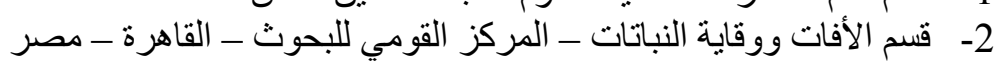

يهدف البحث إلى دراسة بعض النواحى البيولوجية المفترس Stethorus punctillum الذى يعتبر واحدا

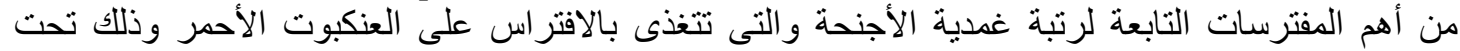

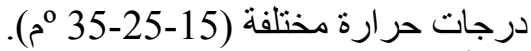

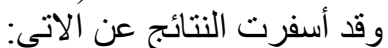

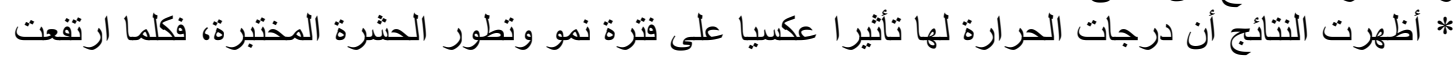

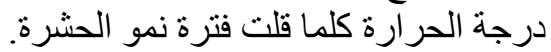

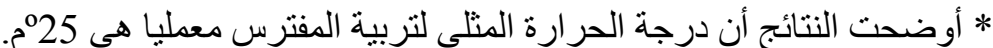

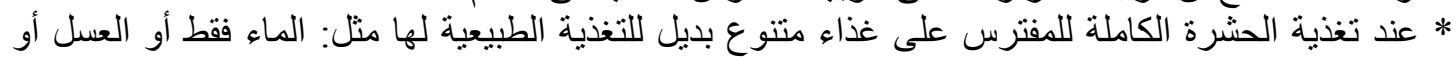

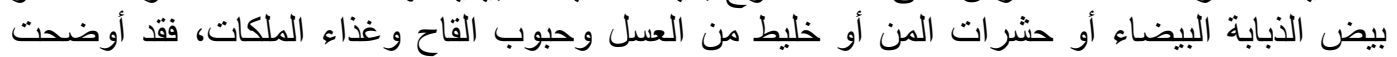

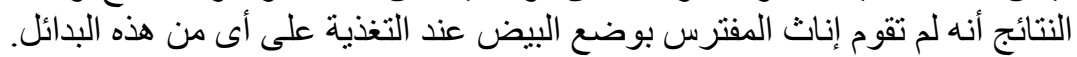

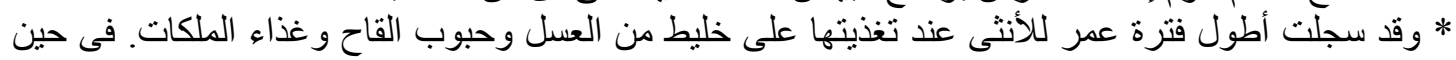

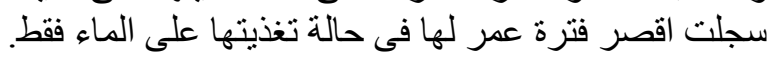

